\title{
Correction to: A Gothic Barcelona?: Carlos Ruiz Zafón's The Cemetery of Forgotten Books Series and Franco's Legacy
}

Xavier Aldana Reyes

Correction to:

Chapter 14 in: H.-G. Millette and R. Heholt (eds.), The New Urban Gothic, Palgrave Gothic, https://doi.org/10.1007/978-3-030-43777-0_14

The original version of this chapter was inadvertently published with incorrect author's given name and family name in chapter title page and running head, which have now been corrected. The corrections to the chapter have been updated with the changes.

The updated version of this chapter can be found at https://doi.org/10.1007/978-3-030-43777-0_14

(C) The Author(s) 2020

H.-G. Millette and R. Heholt (eds.),

The New Urban Gothic, Palgrave Gothic, https://doi.org/10.1007/978-3-030-43777-0_15 